INFLUENCE OF FINANCIAL SECTOR DEVELOPMENT ON ECONOMIC GROWTH

Dilbar Abidova ${ }^{1}$

\begin{abstract}
In the view of every country's endeavors for sustainable economic development, the question of key factors influencing economic growth or recession is becoming more prominent. For several decades now, finance is being considered as one of such factors by some scholars and rejected by others. This article is aimed at analyzing the finance-growth nexus by considering the existing theoretical background, empirical studies, and real life cases. Research has shown that the influence of financial sector on economic growth, and as a result of real sector's activity, is becoming more obvious, especially in the light of the recent global financial-economic crisis. What remains unknown is the extent to which finance can encourage economies to develop.
\end{abstract}

UDC Classification: 330.3, DOI: http://dx.doi.org/10.12955/cbup.v3.600

Keywords: Economy, growth, finance, real sector

\title{
Introduction
}

Economy of any given country is a complex and intricate structure, wherein interaction of different factors and relation of economic sectors play a crucial role in the course of economic development. Although the science of economics has been scrutinized not for one century, some of its issues can be considered as unexplored. Particularly, it is still unclear how financial and real sectors of economy interact and whether the development of finance can directly influence the economic growth of a country. The aim of the present article was to address these questions and analyze the theoretical background, empirical studies, and examples of several countries and draw appropriate conclusions.

For many decades, there has not been a unanimous consensus regarding the role of financial sector in the economy as a whole and its effect on other sectors, especially the real economy. Some scholars argued that it was finance that spurred industrialization era (and further economic growth), while others see an opposite relationship, i.e. the growing economy prompts the financial sector to develop. Additionally, there is a third view, which does not regard the finance-growth nexus as important. Finally, some notable economic growth-related works do not take finance into account at all (Levine, 1997).

However, the increasing number of both theoretical and empirical studies in this direction, as well as real-life country cases, is making it inappropriate to ignore finance as a vital factor of economy. The most prominent proof of how actively finance is involved in the global economy is the latest financial crisis, which clearly caused one of the largest global economic crises (Baily \& Elliot, 2013).

\section{Finance and economic growth}

The linkage between finance and growth and how this interaction works is reviewed by many economists. It is interesting to trace the level of influence of financial sector on economic growth from a practical point of view. Several serious international researches were conducted using a wide range of statistical data collected over a significant time period. The hypothesis of positive relationship between economic growth and the development of financial system was analyzed in the works of such economists as Gurley \& Shaw (1967), Binswanger (1999), Goldsmith (1969), and Zingales \& Rajan (1995).

Some of the most prominent works in the context of finance-growth nexus are the ones by Goldsmith (1969). Having analyzed the data on banking sector of 35 countries for the period of 1860-1963, he came to a conclusion that there is a parallel relationship between financial and economic development in the long-run, and that in most of the cases (with some exceptions) higher growth rates are accompanied by rapidly developing financial system. However, Goldsmith did not approach the issue of cause-effect relation, i.e. whether financial development is a prerequisite for accelerated economic growth. Additionally, Goldsmith's researches do not include (presumably due to lack of data on stock

\footnotetext{
${ }^{1}$ Dilbar Abidova, Tashkent Financial Institute, Uzbekistan, abidova_dilbar@mail.ru
} 
markets) differences among the financial system structure and their influence on economic advancement.

It can be stated that the works mentioned above initiated numerous researches on the topic. A number of such studies, which investigated economic trends in connection with the development of financial institutions over different time periods, determined the notion that regions where more complex and efficient financial system emerged subsequently took leading positions in terms of economic development (Levine, 2002). In particular, the results of several works by Zingales \& Rajan (1998) allow us to make an inference that highly developed financial system promotes emergence of new businesses, whereas advancement of financial institutions and markets substantially accelerates growth of science oriented sectors, such as computer science and pharmaceutics, which require long-term external financing.

In the early 1990s, King and Levine published a work, wherein the indicators of financial development from 77 countries between 1960 and 1989 were analyzed. It was an attempt to find out whether the level of financial development can be used to forecast future economic growth, capital accumulation, and labor productivity rates (King \& Levine, 1993).

One of the comprehensive and structural articles on the topic, as well as one of the most cited ones, is the "Financial Development and Economic Growth: Views and Agenda" (Levine, 1997). The author subdivides the function of finance into 5 categories:

- Facilitation of risk pooling, diversification, trading and hedging

- Resource allocation

- Corporate control and management monitoring

- Saving mobilization

- Facilitation of exchange of products and services

For instance, the asymmetrical information and transaction costs are alleviated thus reducing the risks involved in economic interrelations. The main types of risk considered here are liquidity risk and idiosyncratic risk. The importance of liquidity can be illustrated in the example of industrial revolution in England, which was most probably boosted not by technological innovation but by financial instruments, which allowed increasing liquidity of large long-term investments necessary for developing these innovations (Hicks, 1969). Moreover, special attention should be given to channels through which these functions of finance can encourage (or hinder) economic growth. Levine (1997) outlines two such channels, namely capital accumulation and technological innovation. These channels are incorporated in different growth models, affecting either the rate of capital formation or the rate of technological innovation.

Other authors denote that, while previous theoretical assumptions considered participation of financial sector as a contributor to the economy by creating workplaces and adding to the GDP, the current explanation of the correlation between finance and economy includes similar functions, or as stated by Baily \& Elliott (2013) that the purposes of finance include credit provision, liquidity provision, and risk management services.

Financial systems tend to become more "market-oriented" (i.e. more oriented toward the stock markets), which is in-line with growing standards of living in a given country. Thus, the general propositions of academics are moving toward evaluating the stock markets' development level as a pledge of economic prosperity. Econometric researches of developed markets confirm the synchronism of periods of intensive economic growth and peaks of financial brokerage advancement. According to the World Bank's experts' evaluations, countries with highly developed finance tend to grow $1 \%$ faster per annum 
in the long run. In the countries with higher financial market capitalization rates (in GDP percentage), national wealth is more productive.

In general, all studies on the issue of the influence of financial market on economic growth, starting from the early 90s, can be subdivided into 3 groups, depending on the paradigm followed by the authors (Levine, 2004). The first group is to include works on economic growth, in which impact of financial markets is characterized by non-compliance to some conditions of perfect competition. This approach has microeconomic grounds and is based on researching such problems as moral risk, principal-agent relations, etc., in terms of financial market; their influence on processes of capital accumulation; and, as a consequence, on growth rates.

The second group of works presumes some variables, which describe the functioning of financial markets into models of endogenous economic growth. The main task was tackled by joint efforts of researchers within the framework of these two areas: theoretical proof of positive relationship between financial market's development and economic growth.

The works of the third group, econometric approach, are aimed at finding an empirical proof. The amount of researches, where such proof is obtained is by far more significant than the number of studies which impeach the connection of economic growth to financial market. Nevertheless, this question has yet to be answered. For example, the issue of linearity or non-linearity of the mutual relationship of finance and growth, as well as the direction of this relation (whether finance influences economy or vice versa) remain unresolved. A peculiar integration of these concepts explaining the possibility of nonlinear relationship is the conclusion, which states that the financial market does not have any effect on economic growth in poor countries. Meanwhile, in middle-class countries, there is a clear positive relationship, and it is most prominent there, while developed countries demonstrate a weaker connection of growth to finance (Beck, Demirgüç-Kunt, \& Levine, 2000).

\section{Finance and real sector}

There are a lot of different opinions on the issue of interdependence of real sector and financial sectors of the economy and its influence on the sustainable growth and stability. The effect of financial sector on the real economy is regarded from a slightly different angle, and it is not as widely analyzed as the finance-growth nexus. Nevertheless, the aforementioned views are also applicable to the finance-real sector nexus since general economic growth most inevitably integrates the development of the real sector. The theory that their relationship is not considerable was outlined by Lucas (1988), but has been overruled later, when views of neo-classicism and Modigliani-Miller model, based on the assumption of no transaction costs and perfectly symmetrical information, have come to be considered as purely theoretical and almost non-existent in real life. Therefore, it can be concluded that an advancement in financial systems augments the level of investment by providing capital for new businesses, organizing efficient savings, enabling trade or exchange of products and services, and hedging and diversifying risks. Such enhancement leads to better resource allocation, capital accumulation, and technological progress, all of which contribute to an economic growth in general and the development of the real sector in particular. According to Bjellerup \& Shahnazarian (2012), the interaction between real economy and finance can be illustrated by means of introducing four main channels:

- Interest rate - increase in interest rates means higher borrowing costs, which can lower consumption and investments.

- Bank capital - portrays how the bank operation risks (market, loan, financing) can negatively affect the bank balance sheets. This worsening induces banks to increase their lending rate or decrease the lending itself, both of which result in less investment and consumption. 
- Balance sheet - decline in asset prices (e.g. property or stocks) reduces their value as security for loans. This has a further snowball effect on prices and leads to the drop in consumption and investment (a vivid example is the most recent crisis, which started with mortgage crisis in the US).

- Uncertainty - volatile financial markets cause higher savings and again, lead to low consumption and investment.

The connection of these four transmission channels is depicted in Figure 1.

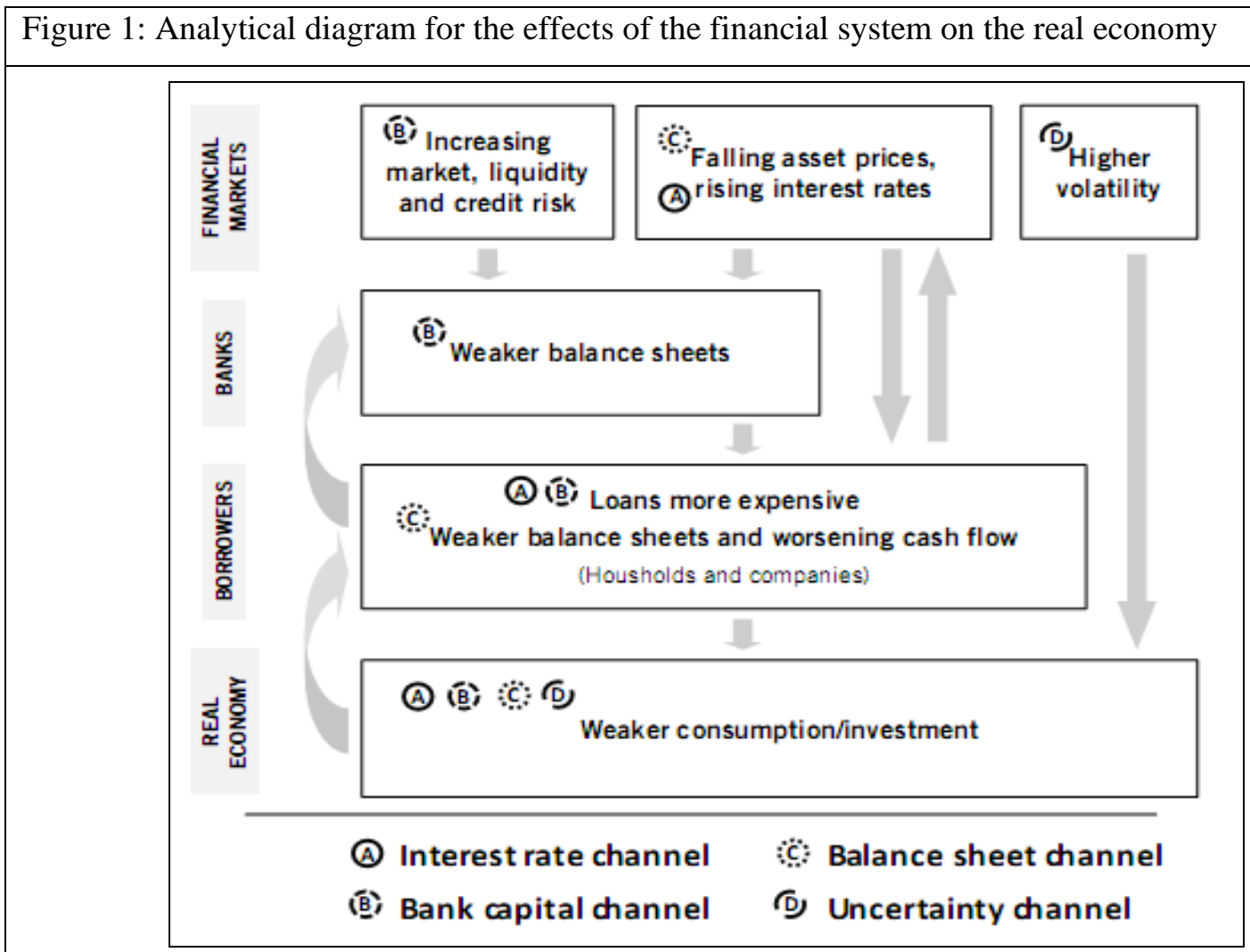

Source: Bjellerup \& Shahnazarian (2012).

As illustrated in Figure 1, it can be concluded that any fluctuations of financial sector are instantly reflected on the real sector. The following information proves the notion that incorrect work of the financial system can lead to serious consequences, such as the global financial-economic crisis.

\section{Case study: USA}

The study of finance and real sector in the US shows that the effect of the so-called "bubble period" in the financial sector of the US has been the main topic of economic disputes over the last several years. This is due to the failure of several large financial institutions in the US. In fact, some of the interest towards the finance-growth nexus has been motivated by the rapid development of the relatively young country's economy, which at the same time possesses the most advanced financial system. It is often argued that the EU's financial system, for example, falls behind the US, as well as the economic growth rates (Thiel, 2001). According to Baily \& Elliot (2013), the financial sector's impact on the overall economy has been measured through its direct contribution to employment and GDP. According to statistical data provided by the Bureau of Labor Statistics (http://www.bls.gov), 6.19 million people were employed in the finance-insurance field of the US economy in 2006. This number dropped to 5.75 
million in 2010 and slightly increased to 5.83 toward 2012. Despite this fact, the financial sector still plays a major role in the US economy and remains an important employer (Baily \& Elliot, 2013).

As represented by Baily \& Elliot (2013), the US economy is highly leveraged and dependent on the availability of debt. At the peak, prior to the crisis, total outstanding debt was equal to about 300 percent of its GDP, which was split among households, government, financial corporations, and non-financial corporations. All exact figures are depicted in Table 1.

\begin{tabular}{|c|c|c|c|c|}
\hline \multicolumn{6}{|c|}{ Table 1: Credit market outstanding debt by sector (in billions of USD in current prices) } \\
\hline Years & Households & Business & $\begin{array}{c}\text { State and local } \\
\text { governments }\end{array}$ & Federal governments \\
\hline 2006 & 12946.5 & 9651.8 & 2690.8 & 4885.3 \\
\hline 2007 & 13830.0 & 10975.5 & 2837.5 & 5122.3 \\
\hline 2008 & 13848.7 & 11660.5 & 2855.4 & 6361.5 \\
\hline 2009 & 13574.2 & 11320.5 & 2968.4 & 7805.4 \\
\hline 2010 & 13198.3 & 11419.8 & 3038.0 & 10453.6 \\
\hline 2011 & 13017.3 & 11966.9 & 2985.3 & 11593.7 \\
\hline 2012 & 12979.6 & 12733.3 & 2980.0 & 12352.8 \\
\hline 2013 & 13105.1 & 13621.8 & 2941.1 & \\
\hline
\end{tabular}

Source: Federal Reserve Statistical Release (2014)

High level of the US indebtedness is related to the deficit in current accounts, which took its roots in 1996 and reached its peak in 2006 when the total deficit constituted 788 billion USD, or 6\% of the GDP (The Economist, 2009). This deficit caused the country to make external savings. This should have prompted the long term interest rate to decrease, indicating that the US was lacking savings. However, when in the mid-2004, the Federal Reserve increased the short term interest rates; this did not affect the long term ones, and they continued to be dragged down. No doubt, the US is one of the biggest world borrowers, but it is surprisingly behind France and the UK or in the middle of the pack in terms of the ratio of debt to GDP. The overall message is that advanced economies all rely on large amounts of borrowing and lending as an important part of the their economic operations (Baily \& Elliot, 2013).

Usually, exporters of capital to the rich countries are emerging markets, since they tend to possess excessive savings and trade balance surplus (e.g. China or oil exporting countries). The reason why they do not use their saving capital is investigated in a series of papers by Caballero \& Farhi (2013). Based on their researches, it can be concluded that financial markets of the countries with transitional economies are not mature enough, thus the domestic supply of financial assets is not reliable for them.

According to Sukharev (2009), the US was the generator of the world financial economic crisis, and the following data were provided:

- The total debt of all agents in 2007 made up 350\% GDP, which exceeded the 1929 debt.

- Debt on bank cards comprised 900 billion USD.

- Debts of American families increased from 46\% of GDP in 1979 to 98\% of GDP in 2007.

- Increase of capital profitability took place at the expense of debt growth. 
- Loss of Bear Stearns Companies’ derivatives constituted about 13.4 trillion Dollars by March, 2008.

- Budget deficit was $12 \%$ of GDP; profit share in the GDP of financial sector was $14 \%$ and $40 \%$ of GDP in 1960 and 2008, respectively.

Figure 3: Total debt of ten largest economies, Q2/2011 (\% of GDP)

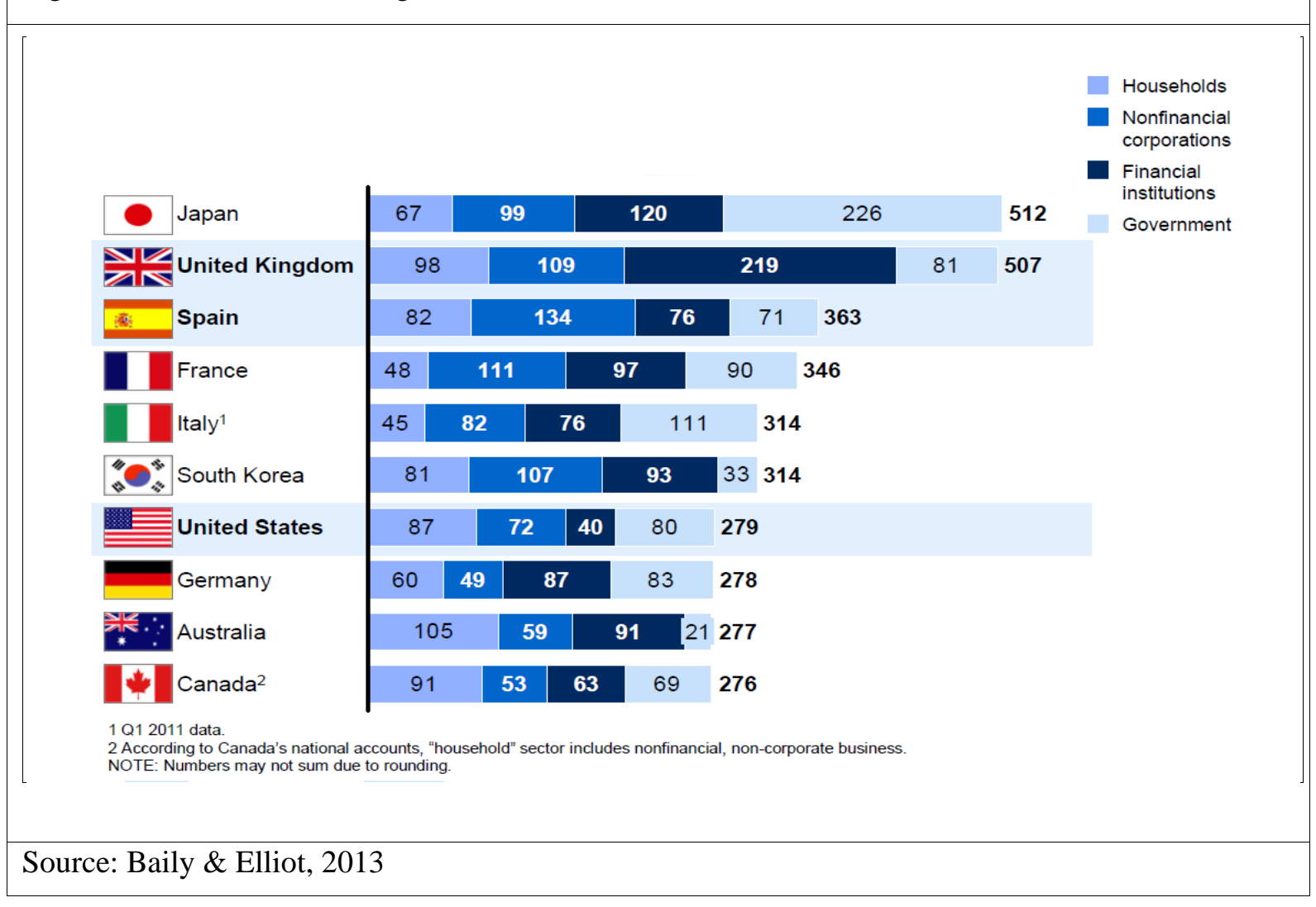

All the numbers listed in the figure and table above support the idea that global financial economic crisis occurred due to incorrect functioning of the world financial system, such as excessive savings and budget surplus in China in-line with deficit in the US, which required replenishment by means of foreign savings. These had negative consequences on the real sector as well. USA being one of the key economies in the world with the largest financial markets and high concentration of global capital simply became the epicenter.

\section{Conclusion}

The analysis of the correlation between financial sector development and economic growth of countries, as well as sensitivity of the real sector to financial market fluctuations, is significant with respect to the existence of economic cycles. The cyclical nature of economy is well known. However, economists still remain ambiguous regarding the most appropriate policies in which governments should undertake to ensure smooth transition from one cycle to another. The recent economic crisis is evident in the lost connection between the financial system and the real sector of the economy.

\section{References}

Baily, M., \& Elliot, D. (2013, July). The Role of Finance in the Economy: Implications for Structural Reform of the Financial Sector.

Beck, T., Demirgüç-Kunt, A., \& Levine, R. (2000). A new database on financial development and structure. Open Access publications from Tilburg University. Tilburg University. 
Binswanger, M. (1999). Co-evolution between the real and financial sectors: the optimistic "New growth theory view” versus the pessimistic “Keynesian view.” Olten: Fachhochsch. Nordwestschweiz.

Bjellerup, M., \& Shahnazarian, H. (2012, November). The Interaction between the Financial System and the Real Economy. 13-23.

Caballero, R., \& Farhi, E. (2013). A Model of the Safe Asset Mechanism (SAM): Safety Traps and Economic Policy. NBER Working Paper No. 18737.

Federal Reserve Statistical Release (2014). Z.1 Financial Accounts of the United States (Q4, 2013). Retrieved from http://www.federalreserve.gov/releases/z1/20140306/z1.pdf

Goldsmith, R. W. (1969). Financial Structure and Development. New Haven and London: Yale University Press.

Gurley, J., \& Shaw, E. (1967). Financial Structure and Economic Development. Economic Development and Cultural Change, 15(3), 257-268.

Hicks, J. R. (1969). A Theory of Economic history. Oxford: Oxford University Press.

King, R. G., \& Levine, R. (1993). Finance and Growth: Schumpeter Might Be Right. Quarterly Journal of Economics, 108(3), 717-737. doi: 10.2307/2118406

Levine, R. (1997, June). Financial Development and Economic Growth: Views and Agenda. Journal of Economic Literature, 35, 688-726

Levine, R. (2002). Bank-Based or Market-Based Financial Systems: Which is Better? NBER Working Paper No. 9138.

Levine, R. (2004). Finance and Growth: Theory and Evidence. NBER Working Paper No. 10766.

Lucas, R. E. (1988). On the Mechanics of Economic Development. Journal of Monetary Economics, 22, 3-42.

Rajan, R., \& Zingales, L. (1998, June). Financial dependence and growth. The American Economic review, 88(3), 559-586.

Sukharev, O. S. (2009). Ecological Efficiency and Functions of Agents Behavior: What Can Economic Theory Say? Bulletin of the University of Perm. Retrieved from http://cyberleninka.ru/article/n/ekologicheskaya-effektivnost-i-funktsiipovedeniya-agentov-chto-mozhet-skazat-ekonomicheskaya-teoriya

The Economist (2009). When a flow becomes a flood. Retrieved from http://www.economist.com/node/12972083

Thiel, M. (2001). Finance and economic growth - a review of theory and the available evidence. Retrieved from http://ec.europa.eu/economy_finance/publications/publication884_en.pdf

Zingales, L., \& Rajan, R. (1995). What Do We Know about Capital Structure? Some Evidence from International Data. Journal of Finance, 50(5), 1421-60. 